PAEDAGOGIA CHRISTIANA

2/26(2010) - ISSN 1505-6872

Michael Meyer-Blanck*

Bonn

\title{
Trynitaryzm, relacja i podmiotowość Nauka o Trójcy Świętej w nauczaniu religii
}

\section{Trójca Święta - pomijany temat nauczania religii?}

„Z nauki o Trójcy Świętej [...] nic bynajmniej nie można uczynić dla praktyki" - tak twierdził już Immanuel Kant w pracy Streit der Fakultäten $(1798)^{1}$. Problematyka trynitarna w niewielkim tylko stopniu jest uwzględniana w praktyce nauczania. W planach nauczania religii teologia trynitarna jest prawie nieobecna, pomijając kwestie wprowadzenia do roku kościelnego i podstawowej struktury katechizmu w nauczaniu konfirmacyjnym. Święto Trójcy Świętej nie jest, jak wiadomo, punktem szczytowym roku kościelnego. Trójca nie znajduje miejsca w codzienności religijnej i dlatego też nie ma dla niej miejsca w nauczaniu.

Niemal w żadnym temacie nie występuje taka rozbieżność pomiędzy naukową teologią a praktyką nauczania. To, co teologia, przynajmniej w ostatnich trzydziestu latach, uważa za centralny model myślowy wiary chrześcijańskiej, w praktyce uznawane jest $\mathrm{w}$ wielu przypadkach za zbędną spekulację lub rodzaj sportu umysłowego; i nie dotyczy to tylko nauczycieli, ale też katechetów i duchowych, którzy na pytanie muzułmanów nieraz odpowiadają że nauka o Trójcy Świętej jest szczególną nauką teologiczną z IV stulecia, powstałą w oparciu o filozofię grecką. Ujęcie to jest reminiscencją

* Prof. Dr Michael Meyer-Blanck jest profesorem pedagogiki religii na Wydziale Teologii Ewangelickiej Uniwersytetu w Bonn. Prezentowany tekst był przedmiotem wykładu w Chrześcijańskiej Akademii Teologicznej w Warszawie w dniu 8 maja 2009 r.

${ }^{1}$ I. Kant, Werksausgabe, tom XI, Frankfurt/M. 1981 (1964), s. 303. 
słynnego poglądu Adolfa von Harnacka, w myśl którego Kościół starożytny filozoficznie skomplikował prostą Ewangelię Jezusa o miłości Ojca oraz o „nieskończonej wartości duszy ludzkiej”, co było związane z „hellenizacją" wiary chrześcijańskiej.

Jeżeli jednak nauczanie szkolne rozumie się, w myśl pięknej formuły Hartmuta von Hentiga, jako zadanie „wzmacniania ludzi, wyjaśnienia rzeczy", to wiara chrześcijańska w swej istocie nie może zostać wyjaśniona bez uwzględnienia właściwych problemów trynitarnych. Jeżeli bowiem Trójcę ujmie się zgodnie z dogmatykiem z Tybingi, Christopherem Schwöbelem, jako „teorię ramową wiary chrześcijańskiej”, to wówczas musi chodzić o coś więcej niż o triadyczne uszeregowane aspektów trzech artykułów wiary. W tym sensie pragnę opowiedzieć się za konkretną tematyzacją zagadnień teologii trynitarnej w nauczaniu.

Dlatego też chciałbym postępować następująco: najpierw opiszę problemy myślowe młodzieży; nie chodzi mi jednak o problemy młodych ludzi, ale o problemy fundamentalne jako takie, które uświadamia sobie młodzież, zaczynając myśleć całościowo i teoretycznie. $\mathrm{Z}$ tej perspektywy dochodzą do głosu również nasze własne podstawowe pytania. Następnie za pomocą kategorii „relacji” i „podmiotowości” zbuduję dwa pomosty dydaktyczne. Trynitarne myślenie może być bowiem powiązane z tym, co po raz pierwszy w wieku młodzieńczym ujawnia się w całej swej głębi: człowiek jest relacją i podmiotowością zarazem - jedno i drugie, jak wiadomo, nie jest łatwe, ale skomplikowane. Inaczej mówiąc: nauka o Trójcy Świętej jako mówienie o Bogu nie jest mniej złożona niż doświadczenie siebie i innych, swoich własnych relacji i podmiotowości.

Przypomnienie tego, co może zostać powiedziane z perspektywy psychologii rozwojowej, sytuuje nasz problem w nowym świetle. Słyszeliśmy, że w wieku młodzieńczym można mówić o ,uwewnętrzeniu, personalizacji i abstrakcji" obrazu Boga². Młodzi ludzie nie myślą o Bogu w kategoriach konkretnego bytu, ale myślą o Nim przez podobieństwa. To właśnie kryje się pod pojęciem ,abstrakcji”: oni wiedzą że chodzi o przenośny sposób mówienia. Jednocześnie obraz Boga ma bezpośredni związek ze zrozumieniem własnej egzystencji - Boga rozumie się indywidualnie i przez refleksję nad samym sobą. Przy możliwych nieporozumieniach można też powiedzieć: młodzież myśli o Bogu przenośnie, egzystencjalnie i autorefleksyjnie. Ujęcie takie otwiera dostęp do kategorii „,podmiotowości” i „relacji”, jak zostały

${ }^{2}$ F. Schweitzer, Lebensgeschichte und Religion. Religiöse Entwicklung und Erziehung im Kindes- und Jugendalter, München 1987, s. 208. 
one rozwinięte w teologii trynitarnej Augustyna czy w XX wieku u Eberharda Jüngela ${ }^{3}$.

W wierze chrześcijańskiej Bóg nie jest pojmowany jako zasada, lecz jako relacja. On nie jest zasada, podobnie jak ja sam i druga osoba nią nie jesteśmy. W stosunku do siebie i do innych zachowuję się żywo, a żywotność oznacza zawsze nieprzewidywalność i zaskoczenia. Bóg jest żywy i zaskakujący, jak ja sam i inni ludzie - Bóg nie jest zasadą filozoficzną ani żadną formułą matematyczną, Bóg ma ciało i krew, życie i miłość. Być może jest to najprostsza formuła trynitarna, jaką może zrozumieć również młodzież. Jeśli sformułuję to w taki sposób, to wynika z tego wyraźnie, że nauka trynitarna jako ,teoria ramowa” jest nie tylko i prawdopodobnie nawet nie w pierwszym rzędzie problemem myślowym. Jest raczej religijnym stylem myślenia, sposobem opowiadania o Bogu, zamiast filozoficznego konstruowania Boga - na tym polega właśnie biblijny i chrześcijański sposób mówienia o Bogu. Bez nauki o Trójcy Świętej nie można prawidłowo mówić o Bogu.

W nauczaniu religii nie mówimy przecież tylko ogólnie o Bogu - to, jak wiadomo, czynią także filozofowie - w nauczaniu religii musimy też mówić o chrześcijańskich odpowiedziach, a te w krótkim streszczeniu brzmią: Bóg jest w historii, Bóg jest relacją i Boga można zrozumieć w analogii do doświadczenia własnej podmiotowości; lub jeszcze krócej i biblijnie: „Bóg był w Chrystusie" (2 Kor 5, 24).

Z tego względu należy wskazywać na to, że właściwe biblijne „dowody” na istnienie Trójcy nie są formułami, które należy wyliczać, jak to na przykład mamy w nakazie chrztu (Mt 28, 18-20: „Idźcie tedy i czyńcie uczniami wszystkie narody, chrzcząc je w imię Ojca i Syna, i Ducha Świętego"). Z trynitarnością spotykamy się nie tylko - i nie pierwotnie - tam, gdzie się liczy do trzech, lecz tam, gdzie uwidocznia się historyczność Boga i jego relacja do Jezusa i do zboru, który w niego wierzy. Trynitarność jest uwarunkowana historycznym rozumieniem Boga, jak to znajdujemy w proroctwach i później w formule historycznej: „Jestem, który jestem” (2. Mż 3, 14). Takie doświadczanie Boga jest przesłanką orędzia Jezusa i orędzia o Jezusie, w które wierzono w społeczności Ducha Świętego.

W dalszej części zajmę się najpierw trzema kwestiami, które sprawiają trudność w myśleniu (2.1 do 2.3), a następnie dwoma dydaktycznymi szansami zrozumienia (3.1 i 3.2).

${ }^{3}$ E. Jüngel, Gott als Geheimnis der Welt. Zur Begründung der Theologie des Gekreuzigten im Streit zwischen Theismus und Atheismus, Tübingen² 1977 (1976). 


\section{Trudności w myśleniu (młodzieży) o Trójcy Świętej}

\subsection{Duch Święty jako „osoba”}

W podstawie programowej nauczania religii ewangelickiej dla drugiego poziomu gimnazjalnego w Nadrenii-Westfalii (odpowiednik polskiego poziomu licealnego - przyp. tłumacza) nauka o Duchu Świętym została podzielona w zasadzie na trzy części, w których obszary tematyczne oznaczono numerami 3-5: Duch w Kościele, Duch w perspektywie nadziei chrześcijańskiej (łącznie z eschatologią) i Duch w działaniu człowieka (etyka). Ujęcie takie jest czytelne. Rodzi się jednak pytanie: Dlaczego w ogóle trzeba mówić o „Duchu Świętym”? Czy Duch jest tylko wyrazem czegoś innego (Kościół, nadzieja, działanie)? Czy Duch w ogóle musi być uwzględniony w nauczaniu? A jeśli sensownie możemy mówić o Kościele, nadziei i działaniu, dlaczego wówczas musimy mówić o Duchu, szczególnie o Duchu jako osobie?

Mówienie przez podobieństwa staje się ważne szczególnie w odniesieniu do pojęcia osoby. Hans Küng, kontrowersyjny teolog katolicki, wyraził to ostatnio w formule: „Bóg jest więcej niż osobą, ale nie jest też mniej niż osobą". Zawsze chodzi o spotkanie, które jest jak spotkanie z ludźmi, a przecież zarazem jest czymś innym niż spotkanie z człowiekiem. Jest to znana średniowieczna figura analogii: via causalitatis, via negativa i via eminentiae. Bóg musi mieć Ducha, jak i my ludzie, ponieważ nasz duch stworzony jest przez Boga (via causalitatis); Boży Duch nie może być taki sam, jak nasz duch, który jest często duchem upartym i nieznoszącym sprzeciwu (via negativa); Boży Duch zawiera wszystko to, co zawiera także nasz duch, jednak na znacznie bardzie złożonym i wyższym poziomie (via eminentiae). Można więc także powiedzieć, że Bóg, w oparciu o analogię, w zróżnicowany sposób może być przedstawiony jako Osoba i Duch. Ale czy o samym Duchu Bożym można myśleć jako o osobie?

Tak w istocie rzeczy sądzi nauka trynitarna. Duch nie jest tylko konceptem myślowym, ale mediatorem i osobą, która pośredniczy między Ojcem i Synem, a także między Ojcem, Synem i wierzącymi. Tak w każdym razie zostało to ujęte w dużym rozdziale o Duchu w Liście do Rzymian: „Duch Chrystusa mieszka w nas, Duch pomaga w naszej niemocy i on sam wstawia się za nami przed Bogiem - jeżeli nie wiemy, o co się modlić - w niewysłowionych westchnieniach" (Rz 8, 26). W sposób oczywisty mówi się tu personalnie. Oczywiście, myśleć należy przy tym za pomocą potrójnej formy analogii z jej ograniczeniami. Ale pomimo tego jest to osobowy sposób mówienia: Chodzi o realny stosunek między Bogiem Ojcem i Bogiem Sy- 
nem, ale też - między wierzącymi i Bogiem. Duch jest relacją, która tworzy dla nas relację. Stąd też nauka trynitarna mówi o Duchu jako o osobie, która tworzy relacje pomiędzy Ojcem i Synem oraz z nami. W dalszej części wrócimy jeszcze do kategorii relacji.

\subsection{Historyczność Boga jako wymóg trynitarnego mówienia o Bogu}

Największe zastrzeżenia wobec wiary chrześcijańskiej, a przede wszystkim wobec Trójcy Świętej, formułują dziś muzułmanie. Wynikają one najpierw z błędnego rozumienia, jakby w nauce o Trójcy Świętej chodziło o przedstawienie antropomorficznego Boga za pomocą obrazu ojca, matki i dziecka. Nawet jeśli ten zarzut zostanie oddalony, pozostaje pytanie, które już wcześniej zostało postawione w kwestii Boga: Czy chrześcijański, trynitarny sposób mówienia o Bogu nie uwłacza transcendencji Boga? Czy nie sprowadza się majestatu Boga do określonych historycznych wydarzeń (Wielkanoc i Zesłanie Ducha Świętego), podczas gdy muzułmanie mówią, że Bóg jest niepojęty, że Bóg w swoich 99 imionach pozostaje niezgłębiony i nieodgadniony, że nie potrafimy o Bogu w ścisłym tego słowa znaczeniu nic powiedzieć i możemy jedynie przestrzegać jego przykazań (jego dobrych ,porad")?

Odnieśmy się wpierw do nieporozumienia dotyczącego nauki o Trójcy Świętej, jakoby chodziło tu o przedstawianie Boga w kategoriach ojca, matki i dziecka. W Koranie mowa jest o tym, że chrześcijanie zafałszowali pierwotne przesłanie Jezusa: w V surze „Stół zastawiony”, gdzie apostołowie proszą Jezusa, aby zwrócił się do Boga o zesłanie z nieba zastawionego stołu (sura V, 111-115) ${ }^{4}$, znajdujemy następujący tekst: „I oto powiedział Bóg: «O Jezusie, synu Marii! Czy to powiedziałeś ludziom: Bierzcie mnie i moją matkę za dwa bóstwa, poza Bogiem?» On powiedział: «Chwała Tobie! Nie do mnie należy mówić to, do czego nie mam prawa. Jeślibym ja tak powiedział, Ty przecież wiedziałbyś o tym. Ty wiesz, co jest w mojej duszy...»" (sura V, 116). I trzecie z końca, bardzo krótkie zdanie sury zatytułowanej „Szczerość wiary” brzmi w całości następująco: „W imię Boga Miłosiernego, Litościwego! Mów: «On - Bóg Jeden, Bóg Wiekuisty! Nie zrodził się i nie został zrodzony! Nikt Jemu nie jest równy!»”" (sura CXII, 1-4).

Khoury wskazuje na to, że zastosowany czasownik ,począł się” (w polskim tłumaczeniu ,zrodził się” - przyp. tłumacza) ma w języku arabskim

${ }^{4}$ Koran, Arabisch-Deutsch übersetzt und kommentiert von Adel Theodor Khoury, Gütersloh 2004; Koran, Z arabskiego przełożył i komentarzem opatrzył Józef Bielawski, Warszawa 1986 . 
treść biologiczną i oznacza „płodzić” lub „wydawać na świat”. Znajdujemy tu echo nicejsko-konstantynopolitańskiego wyznania wiary, gdzie - jak wiadomo - występuje stwierdzenie, że Logos nie został stworzony, lecz „zrodzony”, że jest „współistotny Ojcu”'. Pokazuje to, jak łatwo formuła z 381 roku mogła być mylnie pojmowana w sensie biologicznym. Tak ją zrozumiano w Koranie, i nie tylko tam.

Podczas nauczania należy uświadomić sobie, że w przypadku Trójcy nie chodzi o coś „,biologicznego” czy „dosłownego”, ani też o coś, co należałoby rozumieć ,jakoś symbolicznie". W ten sposób problem trynitarny zostałby zbanalizowany. Można wręcz odnieść wrażenie, że dzięki odniesieniu do „symboliczności” wielu szybko stałoby się usatysfakcjonowanymi. Istota problemu leży jednak w historyczności Boga i pewności, że w historii mamy do czynienia nie tylko z prorokami Boga, ale z „samym Bogiem”. Kwestią otwartą pozostaje rzeczywistość Boga w historii Jezusa i w doświadczeniu Ducha we wspólnocie wierzących.

Najlepiej można to ukazać w kontekście rozumienia nabożeństwa chrześcijańskiego, jak było pojmowane w Nowym Testamencie i od tego czasu w Kościele chrześcijańskim. Nabożeństwo nie jest kultem w sensie oddawania czci, którą jesteśmy Bogu winni, wyrażonej przez modlitwy i rytuały. Chrześcijaństwo nie podziela takiego wyobrażenia antycznej historii religii. Cultus debitus, kult zadośćuczynienia bóstwom został odrzucony. Kościół katolicki reprezentował takie podejście aż do konstytucji liturgicznej II Soboru Watykańskiego z 1963 r. (Sacrosanctum Concilium, cytowane jako SC); jednak po II Soborze Watykańskim - podobnie jak wcześniej u Lutra - perspektywa została radykalnie zmieniona: Bóg sam przychodzi do człowieka i zwraca się do niego. Bóg nie pozostaje w oddaleniu. Podczas nabożeństwa przemawia Bóg, zwraca się do nas w Duchu jako osoba. Drugi Sobór Watykański stwierdza: „[...]Bóg mówi w liturgii do swojego ludu; Chrystus wciąż w niej głosi Radosną Nowinę. Lud odpowiada śpiewem i modlitwą" (SC 33).

W odniesieniu do tej kwestii istnieje ewangelicki i katolicki konsensus: podczas nabożeństwa nie mówimy tylko o Bogu, lecz Bóg sam z nami rozmawia, a my odpowiadamy. W naszej teraźniejszości sam Chrystus w Duchu staje się obecny, ten Chrystus, który jest drogą do Ojca (a nie tylko tę drogę wytycza). W zgromadzeniu w imię Jezusa, podążając za biblijnymi świadkami, spotyka się pełnię samego Boga. Ta obejmująca nas moc, nie jest tylko zwykłą ludzką duchowością, nie jest tylko zwykłym przeczuciem Boga. Jest czymś o wiele więcej - takie jest przekonanie Pawła - tak, że nawet niewie-

5 Tekst zamieszczony w Śpiewniku Ewangelickim, Bielsko Biała 2002, s. 1630: „zrodzony,

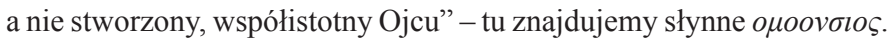


rzący lub nieobeznany mógłby dojść do wniosku, że ,„prawdziwie Bóg jest pośród was" (1 Kor. 14, 25). Moc doświadczona podczas nabożeństwa nie jest „czymś danym od Boga”, jest ona „samym Bogiem”.

Wynika z tego jednak niezbicie: Jeżeli (1) w imieniu Jezusa (2) jego Ojciec ujawnia się jako rzeczywiście działający pośród nas (3), to nie można tego widzieć inaczej, niż tylko w potrójnej refleksji. Ponieważ wszystkie trzy doświadczenia są rzeczywistymi doświadczeniami Boga: Izrael nie modli się do innego Boga, jak do Jezusa; Jezus jest drogą do Ojca i rzeczywistością Ojca w historii, a nie jedynie jakimś opowiadaniem o Ojcu; w nabożeństwie (choć nie tylko tam) spotykamy osobiście działającego pośród nas Syna i Ojca - w Duchu, jak wyrażono to w Gloria Patri: „Chwała niech będzie Ojcu i Synowi i Duchowi Świętemu".

Nauka o Trójcy Świętej służy do tego, aby połączyć różne doświadczenia. W przeciwnym razie mielibyśmy trzy osobne doświadczenia, rozłam pomiędzy Izraelem i Jezusem oraz w teraźniejszości blade pobożne wspomnienie o minionych czasach zbawienia. Mówienie o obecności Ducha byłoby tym samym doświadczane jako ludzko-intelektualny frazes, a nie jako rzeczywistość. Chrześcijańskie doświadczenie Boga w kontekście liturgii ma więc tendencję do ekspresji trynitarnej. Nie ma lepszej możliwości niż mówienie o Duchu, aby dać wyraz doświadczeniu z nabożeństwa: moc Boża staje się realnie obecna w imieniu Jezusa, a tą aktualną mocą jest sam Bóg. W świętowanej Ewangelii spotykamy przez Jezusa samego Ojca, a nie boskość niższego stopnia.

\section{3. „Trzej Bogowie” czy „zasada Boga" - nieporozumienia do omówienia podczas nauczania}

Bóg nie jest religijną zasadą myślową, lecz doświadczeniem miłości i życia. O życiu można prowadzić namysł, nie można go jednak wymyślić ani w myśli skonstruować. Z takiego namysłu powstaje nauka o Trójcy Świętej, którą można podsumować w dwóch tezach:

1. Historyczne doświadczenia ludzi wierzących z Bogiem w Izraelu, Jezusie, historii i teraźniejszości są rzeczywistymi doświadczeniami Boga (a nie ideami o Bogu).

2. Doświadczenia te nie przeczą sobie nawzajem, ale nie są też identyczne. Nie chodzi o trzech bogów, lecz o trzykrotnie tego samego Boga $\mathrm{w}$ różnym historycznym doświadczeniu.

Klasyczne nieporozumienia, którymi zajmował się starożytny Kościół, a następnie historia Kościoła, są więc na tej podstawie łatwe do zrozumienia. Powstają one zawsze wówczas, gdy napięcie opisane przez powyższe 
dwie tezy zostaje pominięte w żywym stosunku Boga do człowieka. Problem polega każdorazowo na tym, że doświadczenie miłości do Boga jest rozmywane przez wprowadzenie zasady łatwo zrozumiałej intelektualnie. Również w religijnym myśleniu człowiek poszukuje uproszczeń, i o tyle jest to zrozumiałe. W tym sensie uczniowie prawdopodobnie sami odkryją większość sposobów myślenia.

2.3.1. Trzy bóstwa (tryteizm). Z tego poglądu wynikają problemy, w kontekście których pojawił się monoteizm. Doświadczenie Boga jest doświadczeniem dziedzinowym dotyczącym danego obszaru i czegoś szczególnego. Im bardziej człowiek porusza się w przestrzeni i czasie, im dalej posuwa się w myśleniu i w podróżowaniu, tym bardziej jest to niezadowalające, ponieważ Bóg wówczas jest tylko bogiem plemienia czy bogiem pewnego obszaru. Wówczas Bóg byłby tylko Bogiem Żydów, Chrześcijan lub Kościoła. Kto jednak ma rację, gdy jedno z drugim się nie pokrywa? Na takim doświadczeniu Boga nie można wówczas polegać, staje się ono niespójne. Tryteizmu nie da się obronić - stąd krytyka muzułmanów jest w tym punkcie uzasadniona (również wówczas, gdy wychodzi poza formę „ojciec, matka, dziecko").

2.3.2. Jedna zasada (modalizm lub sabellianizm). Dla uniknięcia wyżej omówionego problemu, można byłoby powiedzieć, że wszystkie trzy doświadczenia Boga są ostatecznie takie same. Przenośnia, której się wówczas często używa, mówi o wodzie, lodzie i parze. Jest to szczególnie problematyczne, ponieważ sugeruje się, że wszystko jest zrozumiałe i że zna się podstawową zasadę, w tym przypadku „ $\mathrm{H}_{2} \mathrm{O}$ plus stan skupienia”. Takie myślenie zmierzałoby do intelektualnego zawładnięcia Bogiem. Ponadto, nigdy nie mielibyśmy do czynienia z tajemnica, sercem Boga, lecz z czymś nierzeczywistym. W przypadku wody może to być obojętne, jednak nie w przypadku osoby.

Tak jak człowiek chce być kochany jako osoba, a nie jako suma Niemców, urzędników, profesorów (podając siebie samego jako przykład), tak i Bóg chce być postrzegany jako osoba. On zawsze działa jako ktoś, jako całość, a nie jako coś niespójnego. Stąd też poszczególne działania Boga nie mogą być interpretowane jako „działanie wyłącznie Ojca, tylko Syna i wyłącznie Ducha, jakby to wynikało z modalistycznego nieporozumienia w apostolskim wyznaniu wiary, według którego stworzenie pojawia się tylko jako dzieło Ojca"6.

${ }^{6}$ Ch. Schwöbel, Trinitätslehre als Rahmentheorie des christlichen Glaubens, w: W. Härle i R. Preul (red.), Marburger Jahrbuch Theologie X: Trinität, Marburg 1998, s. 143; także: Ch. Schwöbel, Gott in Beziehung. Studien zur Dogmatik, Tübingen 2002, s. 25-51. 
2.3.3. Jeden Bóg i różnorodne „,ienie” Boga (subordynacjonizm, arianizm). Aby uniknąć tego, co właśnie zostało powiedziane, można też wyeksponować inną zasadę i przypisać pełną boskość wyłącznie Bogu Ojcu: tylko on jest wszystkowiedzący, wszechmocny, dobrotliwy i jednocześnie oddalony od człowieka. Można o nim myśleć w sposób radykalnie transcendentny i filozoficzny; Jezus jako pośrednik byłby tylko podobny do niego (jak mówiono w IV wieku przed 381 r.: „Logos nie był opoovøıos, lecz tylko

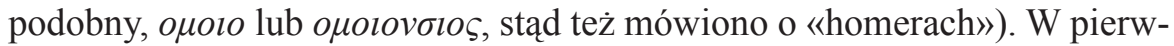
szej chwili wydaje się to wszystko bardzo sensowne, ponieważ jednocześnie myśleć można o boskości Boga, o ludzkim wcieleniu Jezusa i boskiej sile w Jezusie, a także w Duchu Świętym, a zarazem o jedynym w swoim rodzaju Bogu Ojcu. Im dłużej się jednak człowiek nad tym zastanawia, tym bardziej Jezus staje się zwykłym prorokiem, a doświadczane tu działanie Ducha Świętego - samą ideą.

Wszystkie trzy nieporozumienia udowadniają jak ważną rzeczą jest, aby przyjąć za podstawę klasyczną naukę o Trójcy Świętej z IV wieku: Bóg jest Bogiem w jego zwróceniu się do człowieka i jego żywotnym stosunku do świata. Bóg nie jest żadną zasadą i nie jest też sprzecznością. On jest wierny i obdarzony zaufaniem w Izraelu, Jezusie i Duchu - zawsze mamy do czynienia z Bogiem samym, tak że możemy mu zaufać bez ograniczeń.

Wszystko, co nawet w małym stopniu odbiegałoby od tego, zastępowałoby miłość i zaufanie wobec doświadczenia Boga w historii przez doublebind (podwójne wiązanie): Bóg kocha - ale ,jedynie pod warunkiem, że...”; Bóg jest osobą - ale właściwie nie naprawdę. Takie „niewłaściwe” mówienie o Bogu jest jednak religijnie niezadowalające. Trudno jest bowiem modlić się do Boga, który według własnego odczucia, pozostaje niespolegliwy.

\section{Szanse myślowe i wyzwania dla młodzieży: relacja i podmiotowość}

Nauka o Trójcy Świętej jest próbą uniknięcia wymienionych nieporozumień i poważnego traktowania historyczności i możliwości doświadczenia Boga. Chodzi jednak nie tylko o problemy, ale także o szanse. Wszystko to, co w pozytywnym sensie rozumiane jest w nauce o Trójcy Świętej, łatwo można pojać w kategoriach ludzkiej podmiotowości i relacji - przy czym oczywiście mówić będziemy w formie analogii, a więc pozytywnie, w sposób różnicujący i wskazujący na powiązania (via causalitatis, via negativa, via eminentiae). 


\section{1. „Bóg jest relacją”}

Wykorzystując formułę „Bóg jest relacją, doszliśmy do dokonań myśli teologii trynitarnej ostatnich dziesięcioleci, która poprowadzi nas dalej - ma ona wyraźną łączność z teologią dydaktyczną. Tak jak w wieku młodzieńczym poszukuje się zrozumienia bycia sobą przede wszystkim w oparciu o relacje, tak samo można pojąć trynitarność chrześcijańskiego Boga: Bóg utrzymuje nie tylko stosunki z ludźmi, ale Bóg sam w sobie jest relacją. Mówi się przy tym o współwystępowaniu trynitarności historycznej, tzw. trynitarności ekonomicznej (pojęcie pochodzi od ekonomii zbawienia, historii zbawienia) i trynitarności immanentnej, która odnosi się do samego Boga, również niezależnie od jego działania w świecie. W odniesieniu do trynitarności immamentnej ma oczywiście znaczenie, że nie jest ona dostępna naszemu myśleniu i że musimy się wystrzegać chęci posiadania zbyt dużej wiedzy.

Mimo wszystko, myśląc już tylko o człowieku, którego kochamy, wychodzimy z założenia, że jego istota nie będzie inna niż jego działanie i komunikowanie się z nami. Jakość stosunku zostałaby mocno nadwyrężona, gdybyśmy wiedzieli, że dana osoba zawsze tylko udaje, że gdy jest z nami, w rzeczywistości jest zupełnie kimś innym. Z pewnością ostatecznie każdy człowiek jest tajemnicą i nikomu nie możemy spojrzeć w serce, również ukochanej osobie. A jednak, aby pójść jeszcze dalej w tym podobieństwie, liczymy się z tym, że ,ekonomia miłości” najbliższych nam ludzi odpowiada ich ,immanentnej egzystencji”. Chcemy kogoś znać takim, jakim rzeczywiście jest, nie zaś tak, jak on się prezentuje. Stosunek immanencji i ekonomii, bycia i działania staje się dla nas tym ważniejszy, im bliżej kogoś znamy. Stąd też z relacji Boga do świata i człowieka wnioskujemy o Jego wewnętrznej istocie, przechodząc od ekonomii do immanencji.

W nauce o Trójcy Świętej ostatnich dziesięcioleci powiązanie ekonomicznej i immanentnej trynitarności było szczególnie ważne - poprzez trynitarność dowiadujemy się bowiem, w jaki sposób Bóg się objawia i otwiera. Znany teolog soborowy Karl Rahner (1900-1980) sformułował dlatego podstawowy aksjomat: „Trynitarność ekonomiczna jest trynitarnością immanentną, i na odwrót"?.

Kategoria relacji wskazuje na związek pomiędzy trynitarnością ekonomiczną i immanentną, ta zaś prowadzi jednocześnie do przeżyć młodzieży. W psychologii rozwojowej, w nawiązaniu do Eriksona i Fowlera, sformułowano to następująco: osoba dorosła ma relacje, młody człowiek jest relacją.

${ }^{7}$ Cyt. za Ch. Schwöbel, Trinitätslehre, w: Grundlinien der Dogmatik, Rheinbach 2005, s. 81 . 
On sam się doświadcza, a więc to, kim jest, wynika z relacji, które są dla niego ważne. Poprzez relacje rekonstruuje swój własny byt, własną tożsamość. Fowler wyraził to w ładnie brzmiącym zdaniu: I see you seeing me - I see the me I think you see ${ }^{8}$. Przez relacje z innymi człowiek ujmuje świat.

Z punktu widzenia dydaktyki można powiedzieć: Na podstawie rozważania o niezbędności i formie ludzkiej relacyjności można też mówić o relacji Boga ze światem, jak relacje te są wyrażone w nauce o Trójcy Świętej.

\subsection{Ludzka podmiotowość jako struktura analogiczna do Trójcy (vestigium trinitatis)}

Bóg pozwala się poznać nie tylko z perspektywy doświadczenia czegoś innego, lecz również przez doświadczenie samego siebie, a mianowicie w analogii do doświadczenia własnej podmiotowości. Tak przynajmniej brzmi jedno z fascynujących teologicznych przemyśleń Kościoła starożytnego, przedstawione przez Augustyna w De trinitate. Pokazuje ono kolejna możliwość dydaktyczną, zwłaszcza w zakresie nauczania na poziomie licealnym. Tekst Augustyna może być nawet czytany we fragmentach podczas zajęć. Główna myśl nie jest szczególnie skomplikowana: doświadczenie świadomości, własnego umysłu ma wiele wymiarów, które wyraźnie należy rozróżniać. Mimo to świadomość jest jednością, nieoddzieloną i niepodzieloną. Tym niemniej poszczególne części mają każdorazowo własny charakter i nie są po prosto tym samym. W tym sensie, według Augustyna, własna świadomość funkcjonuje w analogii do Trójcy. Świadomość obejmuje tym samym trynitarność jako sensowną formę myślenia o naszym doświadczeniu Trójjedynego Boga. Od czasu Augustyna mówi się więc o vistigia trinitatis, o ,śladach" Trójcy.

W De trinitate Augustyna w księdze X analogiczno-trynitarna struktura jest wykazana w relacji pamięci (memoria), rozumu (inteligentia) i woli (voluntas): świadomość własnej podmiotowości jest śladem stopy (vestigium) trynitarności. Za owo vestigium trinitatis może zostać uznane nie tyle to, co składa się z trzech części, ile to, co jest jednym, a zarazem trzykrotnie różnym i odnoszącym się nierozerwalnie do siebie. Każda z trzech instancji ujmuje ten sam umysł (mens), ale na swój właściwy sposób, a nie w sposób zapożyczony. Zawsze chodzi przy tym o całościowe odniesienie się do siebie samego, w którym mimo wszystko odróżniamy pamięć, rozum i wolę.

8 J. W. Fowler, Studien des Glaubens. Die Psychologie der menschlichen Entwicklung und die Suche nach Sinn, Gütersloh 1991 (oryg. Stages of Faith. The Psychology of Human Development and the Quest for Meaning, San Francisco 1981). 
Streszczając Augustyna: „Odkryliśmy duszę w pamięci, woli i rozumieniu samej siebie. Rozumiejąc, że nie przestaje ona znać i chcieć siebie, zrozumieliśmy przez to samo, że nie ustaje pamięć o sobie, jej rozumienie się i miłość ku samej sobie"9.

Spróbujmy to dokładniej wyjaśnić. Księga X De trinitate może pełnić funkcję edukacyjną - ukazuje ona bowiem wzajemne ujęcie treści teologicznych i relacji człowieka do samego siebie. Na marginesie: chodzi tutaj o tekst, który dla młodzieży nie jest najłatwiejszy i wymaga nieco wysiłku, tym niemniej dla klas, w których uczy się o całkach i różniczkach, jest to tekst odpowiedni. Teksty teologiczne, które są ukierunkowane na odpowiedzialność za świat, nie są w stanie ująć powyższego związku, ponieważ są one rozumiane w kategoriach impulsu do działania. Dla młodych-dorosłych nie jest to jednak temat odległy. Dzieje się tak dlatego, iż dopiero w trzeciej dekadzie życia rozpoczyna się okres religijności indywidualnej i reflektowanej (indywidualnie reflektowana wiara - J. W. Fowler).

Odniesienie do siebie jest czymś, co poprzedza wszelkie myślenie. Taki wgląd w myślenie własnego myślenia ma w sobie coś fascynującego. Element dydaktyczny [tekstu Augustyna De trinitate] tkwi jednak w tym, że w trakcie lektury zapomina się, iż chodzi o tekst teologiczny. Dopiero w ostatnim fragmencie tekstu można zauważyć, że kierowano się tu strukturą myślenia będącą podstawą nauki o Trójcy Świętej:

Te trzy rzeczy - pamięć, intelekt, wola - stanowią jedno życie, a nie trzy; nie tworzą trzech dusz, ale są jedną duszą; a więc nie są trzema substancjami, lecz jedną substancją. Pamięć rozumiana jako życie, duch, substancja, jest bytem absolutnym, pamięć zaś pojęta jako czynność duszy, pozostaje w pewnym stosunku do całości jej istoty, czyli wyraża pewien stosunek. To samo mógłbym powiedzieć o rozumie i woli, gdyż i rozum, i wola wyrażają pewien stosunek. Lecz życie wyraża się zawsze w odniesieniu do niego samego. Tak samo dusza $\mathrm{i}$ istota. Toteż tych troje tworzą jedno życie, jedną duszę i jedną istotę. I wszystko, cokolwiek przypisuje się jednemu z nich absolutnie, to mówi się również o wszystkich razem, nie w liczbie mnogiej lecz pojedynczej ${ }^{10}$.

9 Aurelius Augustinus, De trinitate (łacińsko-niemiecki), Hamburg 2001 (PhB 523) X, 19; O Trójcy Świętej, Poznań, Warszawa, Lublin 1963.

${ }_{10}$ Tamże, X, 18. 


\section{Zakończenie}

Trynitaryzm jako treść nauczania religii nie jest kwestią dowodu, lecz ujęciem struktury teologicznej w kategoriach analogii myślenia o sobie. Jedno i drugie można wyjaśnić, co niekoniecznie oznacza przyjęcie wiary w Trójjedynego Boga. Na tym przykładzie można jednak pokazać, że istnieje myślenie trynitarne niezależne od błędnego rozumowania wyrażonego w tryteizmie czy modalizmie.

$\mathrm{Z}$ tej perspektywy można połączyć trynitaryzm $\mathrm{z}$ antropologią pedagogiczną, która za pomocą pojęcia kształcenia (Bildung) stara się pomóc człowiekowi w odkrywaniu odniesienia do samego siebie, a jednocześnie chronić przed każdą forma pokusy zbyt łatwego racjonalizowania. Dlatego też rozprawy De trinitate nie należy pozostawiać patrystykom i filozofom, lecz wykorzystać jej edukacyjny potencjał dla interpretacji wiary w kategoriach struktury odnoszenia się człowieka do samego siebie (do rokoszowania się, w terminologii Augustyna, uti et frui). Należy także podkreślić, że zaprezentowane podejście jest dla oddalonych od wiary młodych ludzi mniej napastliwe niż dydaktyka tematyzowania problemów świata i egzystencji. Modele myślowe w stylu Augustyna, przy wszystkich ograniczeniach, zawierają istotny potencjał interpretacyjny.

Tłum. Ireneusz Lukas**

\section{Trinität, Beziehung und Subjektivität: Die Trinitätslehre im Religionsunterricht (Zusammenfassung)}

Beim Thema der Trinität im Religionsunterricht geht es in der Schule nicht um einen Wahrheitsbeweis, sondern um das Erschließen einer theologischen Struktur in Analogie zum sich-selbst-Denken. Man kann beides nachvollziehen ohne deswegen die Rede vom dreieinigen Gott glaubend annehmen zu müssen. Aber man kann daran zeigen, dass es ein dreistelliges Denken gibt jenseits des Additiven und des Prinzipiellen (wie dies den Missverständnissen des Tritheismus oder Modalismus entsprechen würde). So wird die Trinitätslehre auch anschlussfähig für die pädagogische Anthropologie, die den Menschen mit Hilfe des Bildungsbegriffes

** Ks. mgr Ireneusz Lukas, asystent w katedrze pedagogiki religii Chrześcijańskiej Akademii Teologicznej w Warszawie, dyrektor Polskiej Rady Ekumenicznej, duchowny Kościoła Ewangelicko-Augsburskiego w RP. 
jeweils in seinem Selbstbezug bei gleichzeitigem Schutz vor jeder Form von Verfügungsrationalität zu denken bestrebt ist. Dies alles sind gute Gründe, Augustins De trinitate nicht den Patristikern und Philosophen zu überlassen, sondern ihn im Sinne der bildenden Erschließung des Glaubens über die Struktur des Selbstbezuges zu verwenden (und zu genießen: uti et frui in Augustins Terminologie). Eine denkerische Annäherung auf Probe ist für junge und glaubensfernere Menschen ein weniger bedrängender Zugang als das Thematisieren der Weltprobleme und der eigenen Existentialität. Darum behalten die Denkmodelle im Stile Augustins bei allen Grenzen viel von ihrer erschließenden Kraft. 